\title{
Clinical and Laboratory Manifestation of Children with Acute Lymphoblastic Leukemia as an Assessment of Severity: A Study in Dr. Hasan Sadikin General Hospital
}

\author{
Yohana Kusuma Angkasa, ${ }^{1}$ Nur Suryawan, ${ }^{2}$ Delita Prihatni ${ }^{3}$ \\ ${ }^{1}$ Faculty of Medicine Universitas Padjadjaran, ${ }^{2}$ Department of Child Health Faculty of Medicine \\ Universitas Padjadjaran/Dr. Hasan Sadikin General Hospital, Bandung, Indonesia, ${ }^{3}$ Department \\ of Clinical Pathology Faculty of Medicine Universitas Padjadjaran/Dr. Hasan Sadikin General \\ Hospital, Bandung, Indonesia
}

\section{Abstract}

Background: Acute lymphoblastic leukemia (ALL) is a disease caused by a mutation of lymphoid progenitor cells in bone marrow, that induces uncontrolled lymphoid cell proliferation. ALL is the most common type of leukemia in children. Various clinical and laboratory manifestation makes the diagnostic process more complicated. This study aimed to observe the clinical and laboratory manifestation of children with ALL in Dr. Hasan Sadikin General Hospital for diagnostic and assessment. Methods: The design of this study was a descriptive cross-sectional with a total sampling method. Data of all children under 18 years old with ALL diagnosed in 2015 to 2017 were included. The diagnosis of ALL was confirmed by examination of hematology indices, peripheral blood smear, and bone marrow aspiration classified by FAB. Inaccessible or incomplete medical records were excluded.

Results: In total, 192 data of ALL patients were included. Most ALL patients predominantly occurred in boys (59.9\%), and the age group of $1-5$ years old $(40.6 \%)$. The clinical manifestations were pallor $(89.6 \%)$, hepatomegaly $(79.7 \%)$ and fever $(75 \%)$. Most patients experienced severe anemia with hemoglobin level $<7 \mathrm{~g} / \mathrm{dL}$ (44.8\%), leukocytosis $>20.000$ cells $/ \mathrm{mm} 3$ (46.9\%), severe thrombocytopenia with platelet count $<20.000$ cells $/ \mathrm{mm} 3(51 \%)$, and blast cells count $>50 \%(45.3 \%)$. Based on FAB classification, the majority of the patients were classified as ALL type L2 (65.6\%).

Conclusions: Clinical and laboratory manifestation of ALL patients can be used as a parameter for diagnostic and assessment of severity. Earlier diagnosis would result in better prognosis and more precise treatment for ALL patients.

Keywords: Acute lymphoblastic leukemia, ALL, severity

\section{Introduction}

Mutation of lymphoid progenitor cells in the bone marrow which induces excessive and uncontrolled lymphoid cell proliferation causes acute lymphoblastic leukemia (ALL). ${ }^{1}$ Acute lymphoblastic leukemia is the most common leukemia diagnosed in children with the highest prevalence of rate in children aged 2-5 years old and predominantly in boys. $^{2,3,4}$ Twenty-six percent of all malignancy cases diagnosed in the USA in 2014 is acute lymphoblastic leukemia. ${ }^{3}$ It is also one of the malignancies with high incidence rate in Indonesia, as shown in Dr. Hasan Sadikin General Hospital reports where fifty-one new cases of ALL had been found in 2010-2011, while 76 new cases were found in 2014..$^{5,6}$ It is known that half of the pediatric patients with malignancy in 2006 had been admitted to Dharmais National Cancer Hospital with advanced stage condition. Lack of knowledge about any signs or symptoms of the disease has been the cause of such conditions. ${ }^{7}$

Clinical features presenting in ALL are various. Generally, the first signs and symptoms are often non-specific which caused by anemia, such as irritability, anorexia, weakness, and pallor. Fever and infection might occur due to neutropenia, while thrombocytopenia might cause hemorrhages. Leukemic cells could infiltrate various organs resulting in other clinical features including hepatomegaly, splenomegaly, lymphadenopathy, and even

Correspondence: Yohana Kusuma Angkasa, Faculty of Medicine Universitas Padjadjaran,Jalan Raya Bandung-Sumedang Km.21, Jatinangor, Sumedang, Indonesia, Email: yohanaksma@gmail.com 
nerve involvement. ${ }^{4}$

Diagnosis and classification ALL can be determined based on clinical and laboratory examination. Data supporting diagnosis can be obtained from peripheral blood smear examination or bone marrow aspiration. ${ }^{8}$ Early signs of ALL can be observed as abnormal blood examination, which is anemia, thrombocytopenia, and leukocytosis. Blast cells commonly found in the peripheral blood smear. Bone marrow aspiration acts as the gold standard in diagnosing ALL. When bone marrow aspiration result shows more than 5\% of blast cells count, we can presume the patient as having leukemia; while for ALL definite diagnosis, more than $20 \%$ on blast cells count is needed. Differentiation of ALL and AML will be determined by cell morphology obtained from bone marrow aspiration classified based on French American British (FAB) classification. This classification depends on cell size, chromatin, nucleoli, and cytoplasm. ${ }^{4}$ Classification based on the World Health Organization (WHO) can be done if the sample is examined using molecular method and then flow cytometri. ${ }^{9}$ Dr. Hasan Sadikin General Hospital's procedure for diagnosing ALL consists of anamnesis, physical and laboratory examination such as hematology indices, peripheral blood smear, and bone marrow examination. ${ }^{5}$

Data on clinicaland laboratory manifestation of ALL in children in Dr. Hasan Sadikin General Hospital Bandung is still unknown. Aim of this study was to give more information on clinical and laboratory manifestation of ALL in children in Dr. Hasan Sadikin General Hospital Bandung. This information could help in detecting and diagnosing ALL leading to more precise treatment and better prognosis.

\section{Methods}

The design of this study was a descriptive cross-sectional study. Data were obtained from inpatient Medical Record Unit Dr. Hasan Sadikin General Hospital Bandung during 2015-2017. Subjects were all medical records of children who had been diagnosed with ALL for the first time in Dr. Hasan Sadikin General Hospital and confirmed with hematology examination, peripheral blood smear, and bone marrow aspiration, with total sampling method. Exclusion criteria were inaccessible or incomplete medical records.

Clinical manifestations data was collected, including pallor, fever, hemorrhage, seizure, infiltrative presentation (hepatomegaly, splenomegaly measured by schuffner line which depends on enlargement of spleen measured from left costal margin to right anterior superior iliac spine, and lymphadenopathy); as well as and laboratory data, including hematological examination (hemoglobin, leukocyte, thrombocyte), peripheral blood smear for blast cell counting, and bone marrow aspiration to classify ALL based on FAB classification, depending on morphological including cell size, chromatin, nucleoli, and cytoplasm. ${ }^{4}$

Data were obtained from the medical record after Ethical Clearance was granted, issued by the Research Ethics Committee of Universitas Padjajaran Bandung (No. 219/ UN6.KEP/EC/2018) and Research Licensing Letter issued by the Research Ethics Commitee of Dr. Hasan Sadikin General Hospital Bandung (No. LB.02.01/X.2.2.1/9373/2018.) Data were presented in tables.

Table 1 Characteristics of Acute Lymphoblastic Leukemia Patients

\begin{tabular}{lcc}
\hline & \multicolumn{2}{c}{ Total } \\
\cline { 2 - 3 } & $\mathbf{N}$ & $\mathbf{\%}$ \\
\hline Gender & & \\
$\quad$ Boy & 115 & 59.9 \\
$\quad$ Girl & 77 & 40.1 \\
Age & & \\
$\quad<1$ year old & 7 & 8.9 \\
$>1-5$ years old & 78 & 40.6 \\
$>$ 5-10 years old & 56 & 29.2 \\
$>10-18$ years old & 41 & 21.4 \\
\hline
\end{tabular}




\section{Results}

There were 192 subjects from 284 medical records complying inclusion criteria. Most of the excluded medical records were due to inaccessibility or insufficiency data.

As shown in Table 1, the highest incidence rate occurred in boys (155 patients, 59.9\%) and children with age category of $>1-5$ years old (78 patients, $40.6 \%$ ).

The clinical features of ALL were shown in Table 2. Pallor was the most common presenting complaint (n172;89.6\%), followed by fever (n144; 75\%). As for clinical findings, hepatomegaly was mostly found (n 153;79.7\%), classified into less than $5 \mathrm{~cm}$ enlargement group (n117;60.9\%), while hemorrhage was mostly seen as skin manifestations (n63;32.8\%). Lymph node enlargement was found (n131; 68.2\%) with cervical as the most affected area; and Schuffner I-II, as the most common grade of splenomegaly, was detected (n72; 37.5\%).

Severe anemia $(\mathrm{Hb}<7 \mathrm{~g} / \mathrm{dL})$ was seen $(\mathrm{n} 86$; $44.8 \%)$, where asleucocytosis was found (n90; 46.9\%). Most patients (n98; 51\%)

Table 2 Clinical Manifestation of Acute Lymphoblastic Leukemia Patient

\begin{tabular}{|c|c|c|}
\hline \multirow{2}{*}{ Clinical Features } & \multicolumn{2}{|c|}{ Total } \\
\hline & $\mathbf{N}$ & $\%$ \\
\hline Pallor & 172 & 89.6 \\
\hline Fever & 144 & 75 \\
\hline \multicolumn{3}{|l|}{ Hemorrhage } \\
\hline Gum & 44 & 22.9 \\
\hline Epistaxis & 27 & 14.1 \\
\hline Skin & 63 & 32.8 \\
\hline GI Tract & 15 & 7.8 \\
\hline Intracranial & 1 & 0.52 \\
\hline Eye & 5 & 2.6 \\
\hline Urinary Tract & 2 & 1 \\
\hline Others & 9 & 4.7 \\
\hline Seizure & - & - \\
\hline \multicolumn{3}{|l|}{ Lymphadenopathy } \\
\hline Cervical & 131 & 68.2 \\
\hline Axillary & 22 & 11.5 \\
\hline Inguinal & 36 & 18.8 \\
\hline Others & 3 & 1.6 \\
\hline \multicolumn{3}{|l|}{ Hepatomegaly } \\
\hline$<5 \mathrm{~cm}$ & 117 & 60.9 \\
\hline $5-10 \mathrm{~cm}$ & 34 & 17.7 \\
\hline$>10 \mathrm{~cm}$ & 2 & 1 \\
\hline \multicolumn{3}{|l|}{ Splenomegaly } \\
\hline Schuffner I-II & 72 & 37.5 \\
\hline Schuffner III-IV & 49 & 25.5 \\
\hline Schuffner V-VI & 2 & 1 \\
\hline Schuffner VII-VIII & - & - \\
\hline
\end{tabular}


Table 3 Laboratory Features of Acute Lymphoblastic Leukemia Patients

\begin{tabular}{|c|c|c|c|}
\hline \multicolumn{2}{|c|}{ Laboratory Features } & \multicolumn{2}{|c|}{ Total } \\
\hline & & $\mathbf{N}$ & $\%$ \\
\hline \multirow[t]{19}{*}{ Hematology } & Hemoglobin (g/dL) & & \\
\hline & $<7$ & 86 & 44.8 \\
\hline & $7-9.9$ & 73 & 38 \\
\hline & $10-10.9$ & 16 & 8.3 \\
\hline & $\geq 11$ & 17 & 8.9 \\
\hline & Leukocyte(cells/mm3) & & \\
\hline & $<10,000$ & 76 & 39.6 \\
\hline & $10,000-20,000$ & 26 & 13.5 \\
\hline & $>20,000$ & 90 & 46.9 \\
\hline & Thrombocyte (cells/mm3) & & \\
\hline & $<20,000$ & 98 & 51 \\
\hline & $20,000-50,000$ & 58 & 30.2 \\
\hline & $>50,000-100,000$ & 21 & 10.9 \\
\hline & $>100,000-150,000$ & 8 & 4.2 \\
\hline & $>150,000$ & 7 & 3.6 \\
\hline & Blast cell count & & \\
\hline & $<20 \%$ & 50 & 26 \\
\hline & $20-50 \%$ & 55 & 28.6 \\
\hline & $>50 \%$ & 87 & 45.3 \\
\hline \multirow[t]{3}{*}{ Bone Marrow Aspirations } & L1 & 21 & 10.9 \\
\hline & L2 & 126 & 65.6 \\
\hline & L3 & 5 & 2.6 \\
\hline
\end{tabular}

were classified into severe thrombocytopenia group. Blast cell count $>50 \%$ acquired from peripheral blood smear examination was also found (n 87; 45.3\%) as shown in Table 3.

Furthermore, there were 33 samples of 192 ALL patients whose bone marrow aspiration (BMA) classification based on FAB was not listed in the medical records. For further classification, 2 patients were classified as bilineage leukemia, 2 as early phase leukemia, and 3 others as preleukemia. The most common type of ALL based on FAB classification was L2 (n 126; 65.6\%), whereas L1 and L3 were found in $21(10.9 \%)$ and $5(2.6 \%)$ patients, respectively.

\section{Discussions}

Our study has shown that acute lymphoblastic leukemia (ALL) has been predominantly occurred in boys and children aged $>1-5$ years old, consistent with several previous studies in some parts of the world as reported from the USA and Southern China. ${ }^{10,11}$

Acute lymphoblastic leukemia patients have various clinical features. Infiltration of blast cells to bone marrow would suppress normal cell proliferation which caused varied presentations in each patient. The earliest manifestations are caused by anemia resulting in pallor and weakness, thrombocytopenia resulting in bleeding, and neutropenia resulting in fever. ${ }^{4}$ Pallor, hepatomegaly, and fever are found to be the most common presenting clinical manifestation of ALL. This is consistent with findings from previous studies that fever, pallor, and hepatosplenomegaly are the main presenting complaints of ALL. ${ }^{12,13}$

In addition to their infiltration to bone 
marrow, leukemic cells also infiltrate other organs. Spleen, liver, and lymph nodes are the most common infiltrated organs. ${ }^{4}$ As seen in this study where hepatomegaly, splenomegaly, and lymphadenopathy are commonly presented in ALL patients. Similarly, reported in Iran, where main extramedullary symptoms are splenomegaly, followed by hepatomegaly and lymphadenopathy. ${ }^{14}$

Blood examinations in ALL patients will commonly show anemia, thrombocytopenia, and leukocytosis. These abnormalities are due to uncontrolled and excessive lymphoid cell proliferation and blast cells infiltrations to bone marrow which caused suppression of normal cell proliferation. ${ }^{4}$ As shown in this study, most of the patients have severe anemia $(<7 \mathrm{~g} / \mathrm{dL})$. These findings are similar to other reports where a large proportion of ALL patients are classified for having severe anemia. ${ }^{12,15}$ Leukocytosis is commonly presented in ALL patients. Similarly to the findings in Iran and Brazil, where most patients have leukocytosis. ${ }^{14,16}$ The majority of the patients have severe thrombocytopenia or decreased platelet count. ${ }^{17}$ Similarly founded in Brazil where the majority of their ALL patients have thrombocytopenia. ${ }^{15}$

The differentiation process of lymphoid cells is blocked in ALL patients, while their production and proliferation are uncontrolled, which result in blast cells findings in peripheral blood smear and bone marrow. ALL can be presumed with blast cells count results $>5 \%$, however for definite diagnosis of ALL, $20 \%$ blast cells or more is needed. ${ }^{4}$ Based on the result from peripheral blood smear, a large proportion of ALL patients have $>50 \%$ of blast cells. This result was in sync with another study in Indonesia which reported that in almost ALL cases, peripheral blood smear would present higher blast cells count. ${ }^{17}$ Based on this study, the majority of the patients classified as L2 type. Similarly found in Eastern Iraq and India, where the most dominant type was L2, followed by L1 and L3. ${ }^{12,18}$

The limitation of this study was inaccessible medical record data or incomplete data which caused data to be excluded, resulting in a lower sample population.

To conclude, acute lymphoblastic leukemia(ALL) cases predominantly occur in boys and children between 1-5 years old. Pallor, hepatomegaly, and fever are the main presenting clinical features, while the most common laboratory features found in children with ALL are severe anemia, leukocytosis, and severe thrombocytopenia, with blastcells count
$>50 \%$. ALL L2 is the most common type of ALL based on FAB classification. By understanding clinical and laboratory manifestation of ALL, this will help in the diagnosis and assessment of severity which, and thus better prognosis and more precise treatment.

\section{References}

1. Terwilliger $\mathrm{T}$, Abdul-Hay $\mathrm{M}$. Acute lymphoblastic leukemia: a comprehensive review and 2017 update. Blood Cancer J. 2017;7(6):e577.

2. Starý J, Hrušák O. Recent advances in the management of pediatric acute lymphoblastic leukemia. F1000Res. 2016;5:2635.

3. Ward E, DeSantis C, Robbins A, Kohler B, Jemal A. Childhood and adolescent cancer statistics. CA Cancer J Clin. 2014;64(2):83103.

4. Roganovic J. Acute lymphoblastic leukemia in children. In: Guenova $M$, editor. Leukemia. London: InTech Open; 2013. p. 39-74.

5. Suryawan N, Idjradinata P, Reniarti L. Hubungan subtipe sel limfosit dengan tingkat remisi pascakemoterapi fase induksi leukemia limfoblastik akut. Sari. Pediatri. 2017;18(6):448-52.

6. Inten $Y$, Reniarti L, Chairulfatah A. Hubungan kadar procalcitonin dengan demam neutropenia pada leukemia limfoblastik akut anak. Sari Pediatri. 2015;17(38):267-72.

7. Tehuteru ES. Mewaspadai gejala kanker pada anak. Buletin Jendela Data \& Informasi Kesehatan. 2015;Semester $1: 25-9$.

8. Tanzilia MF, Cahyadi A, Hernaningsih Y, Retnowati E, Ugrasena IDG. CD4+ T-cell, CD8+ T-cell, CD4+/CD8+ ratio, and apoptosis as a response to induction phase chemotherapy in pediatric acute lymphoblastic leukemia. Paediatr Indones. 2017;57(3):138-43.

9. Abdul-hamid G. Classification of acute leukemia. In: Antica $M$, editor. Acute Leukemia: The Scientist's Perspective and Challenge. London: InTech Open. 2011p.

10. Barrington-Trimis JL, Cockburn M, Metayer C, Gauderman WJ, Wiemels J, McKeanCowdin R. Trends in childhood leukemia incidence over two decades from 19922013. Int J Cancer. 2017;140(5):1000-8.

11. Li SY, Ye JY, Meng FY, Li CF, Yang MO. Clinical characteristics of acute lymphoblastic 
leukemia in male and female patients: A retrospective analysis of 705 patients. Oncol Lett. 2015;10(1):453-8.

12. Shalal HH, Mahmood NS, Alchalabi MAQ. Clinical, hematological, and laboratory presentation of acute lymphoblastic leukemia of children in Diyala province/ Eastern Iraq. Int J Res Med Sci. 2017;5(10):4227-33.

13. Omari AS Al, Hussein TA, Albarrak KA, Habib AK, Sambas AA, Sheblaq N, et al. Clinical characteristics and outcomes of acute lymphoblastic leukaemia in children treated at a single tertiary hospital in Riyadh , Saudi Arabia. Journal of Health Specialties. 2018;6(1):14-8.

14. Pahloosye A, Hashemi AS, Mirmohammadi SI, Atefi A. Presenting clinical and laboratory data of childhood acute lymphoblastic leukemia. Iran J Ped Hematol Oncol. 2011;1(3):71-7.
15. Lustosa de Sousa DW, de Almeida Ferreira FV, Cavalcante Félix FH, de Oliveira Lopes MV. Acute lymphoblastic leukemia in children and adolescents: Prognostic factors and analysis of survival. Rev Bras Hematol Hemoter . 2015;37(4):223-9.

16. Ibagy A, Silva DB, Seiben J, Winneshoffer AP, Costa TE, Dacoregio JS, et al. Acute lymphoblastic leukemia in infants: 20 years of experience. J Pediatr (Rio J). 2013;89(1):64-9.

17. Rahadiyanto KY, Liana P, Indriani B. Pola gambaran darah tepi pada penderita leukimia di Laboratorium Klinik RSUP Dr. Mohammad Hoesin Palembang. MKS. 2014;46(4):259-65.

18. Singh G, Parmar P, Kataria SP, Singh S, Sen R. Spectrum of acute and chronic leukemia at a tertiary care hospital , Harayana, India. Int J Res Med Sci. 2016;4(4):1115-8. 